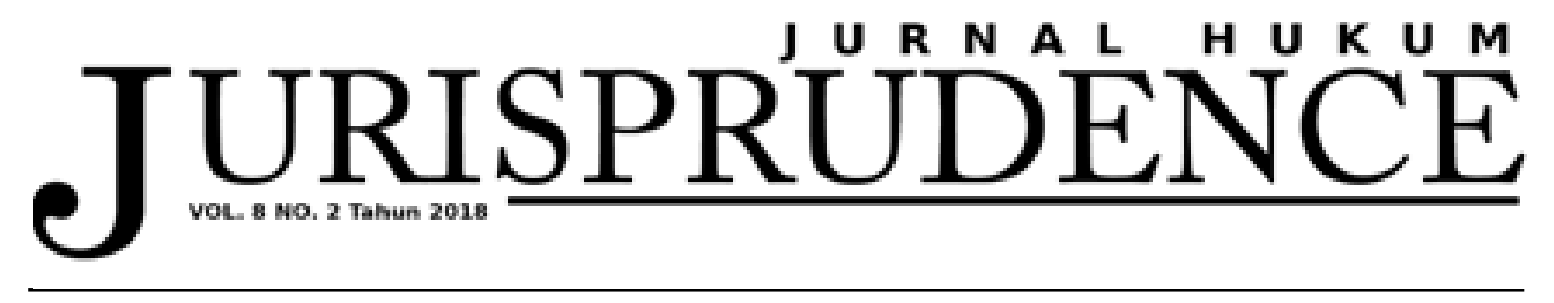

\title{
PEMUNGUTAN PAJAK PERTAMBAHAN NILAI TERHADAP BITCOIN SEBAGAI OBYEK JUAL BELI DI INDODAX.COM
}

\author{
Zidna Aufima \\ Magister Kenotariatan Universitas Airlangga \\ Email: zidna.aufima-2016@fh.unair.ac.id
}

\begin{abstract}
ABSTRAK
Para pelaku perdagangan yang melakukan jual beli bitcoin di Indodax.com. masih ada yang belum menyertakan pendapatannya dari perdagangan bitcoin di indodax.com. dalam Surat Pemberitahuan Tahunan yang kemudian dilaporkan ke Direktorat Jenderal Pajak. Metode yang digunakan adalah statute approach dan conceptual approach. Hasil penelitian ini dapat diketahui bahwa seharusnya para pelaku perdagangan yang melakukan jual beli bitcoin di Indodax.com menyertakan pendapatannya dari perdagangan bitcoin di indodax.com. atau memasukkan setiap keuntungan yang diperoleh dari kegiatan trading bitcoin di Indodax.com. dalam Surat Pemberitahuan Tahunan kemudian dilaporkan ke Direktorat Jenderal Pajak.
\end{abstract}

Kata Kunci : Pajak Pertambahan Nilai, Bitcoin, Jual Beli, Indodax.com.

\section{A. PENDAHULUAN}

Pengertian Pajak adalah iuran wajib ke dalam kas negara berdasarkan peraturan perundang-undangan, tanpa adanya tegen prestasi (prestasi kembali) secara langsung, yang hasilnya dipergunakan untuk membiayai kegiatan-kegiatan pembangunan (public investment), yang apabila ada kelebihannya menjadi tabungan negara (public saving). ${ }^{1}$ P.J.A Adriani berpendapat bahwa pajak adalah iuran kepada negara yang dapat dipaksakan, yang terhutang oleh yang wajib membayarnya menurut peraturan perundang-undangan, dengan tidak mendapat prestasi kembali yang langsung dapat ditunjuk, yang gunanya untuk membiayai pengeluaran-pengeluaran umum berhubungan dengan tugas negara untuk menyelenggarakan pemerintahan. ${ }^{2}$

Pembagian pajak dapat dilakukan berdasarkan golongan, wewenang pemungut maupun sifatnya. Berdasarkan golongan dibedakan atas pajak langsung dan pajak tidak langsung. Berdasarkan wewenang pemungut dibedakan atas pajak pusat dan pajak daerah. Berdasarkan sifatnya dibedakan atas pajak subjektif dan pajak objektif. Pajak langsung adalah pajak yang bebannya harus ditanggung sendiri oleh wajib pajak yang bersangkutan dan tidak dapat dialihkan kepada pihak lain. Contohnya pajak penghasilan. Pajak tidak langsung

1 Rochmat Soemitro, Asas dan Dasar Perpajakan, Refika Aditama, Bandung, 2005, hal. 2.

2 R. Santoso Brotodiharjo, Pengantar Ilmu Hukum Pajak, Refika Aditama, Bandung, 2005, hal. 2. adalah pajak yang bebannya dapat dialihkan kepada pihak lain. Contohnya pajak pertambahan nilai dan pajak penjualan atas barang mewah. Pajak Pusat (pajak negara) adalah pajak yang wewenang pemungutannya ada pada pemerintah pusat yang pelaksanannya dilakukan oleh Departemen Keuangan melalui ${ }^{3}$ Direktorat Jenderal Pajak. Pajak pusat diatur dalam undang-undang dan hasilnya akan masuk ke Anggaran Pendapatan dan Belanja Negara. Pajak Pusat contohnya pajak penghasilan, pajak pertambahan nilai dan pajak penjualan atas barang mewah serta bea meterai. Pajak daerah adalah pajak yang wewenang pemungutannya ada pada Pemerintah Daerah yang pelaksanaannya dlakukan oleh Dinas Pendapatan Daerah. Contoh pajak daerah adalah Pajak Bumi dan Bangunan dan Bea Perolehan Hak Atas Tanah dan Bangunan. Pajak Daerah digolongkan menjadi 2 yaitu: ${ }^{4}$

\section{Pajak Provinsi Terdiri Atas:}

a. Pajak kendaraan bermotor \& kendaraan di atas air;

b. Bea balik nama kendaraan bermotor \& kendaraan diatas air;

c. Pajak bahan bakar kendaraan bermotor;

d. Pajak pengambilan \& pemanfaatan air bawah

3 Deddy Sutrisno dan Indrawati, Bahan Ajar Mata Kuliah Hukum Pajak, Fakultas Hukum Universitas Airlangga, Surabaya, 2009, hal. 21.

4 bid. hal. 22. 
tanah \& air permukaan.

2. Pajak Kabupaten atau Kota Terdiri Dari: Pajak hotel, pajak restoran, pajak hiburan, pajak reklame, pajak penerangan jalan, pajak pengambilan bahan galian golongan C, pajak parkir, Pajak Bumi dan Bangunan serta Bea Perolehan Hak atas Tanah dan Bangunan.

Pajak Pertambahan Nilai (PPN) adalah Pajak atas konsumsi barang dan jasa di daerah Pabean yang dikenakan secara bertingkat di setiap jalur oleh perkembangan transaksi bisnis serta pola konsumsi masyarakat yang merupakan objek dari Pajak Pertambahan Nilai. Perkembangan ekonomi yang sangat dinamis baik di tingkat nasional, regional maupun internasional terus menciptakan jenis serta pola transaksi bisnis yang baru.5 Pajak Pertambahan Nilai (PPN) diatur dalam Undang-Undang Nomor 42 Tahun 2009 tentang Perubahan Ketiga Atas Undang-Undang Nomor 8 Tahun 1983 tentang Pajak Pertambahan Nilai Barang dan Jasa dan Pajak Penjualan atas Barang Mewah (selanjutnya disebut UU Pajak Pertambahan Nilai Barang dan Jasa dan Pajak Penjualan atas Barang Mewah). Mulai Tanggal 9 November 2016, semua biaya untuk jual beli bitcoin yang terjadi di indodax.com. sudah termasuk Pajak Pertambahan Nilai (PPN) sebesar 10\%. Para member indodax.com. selaku para pelaku perdagangan (traders) yang melakukan jual beli bitcoin di Indodax.com. masih ada yang belum menyertakan pendapatannya dari perdagangan bitcoin di indodax.com. atau belum memasukkan setiap keuntungan yang diperoleh dari kegiatan trading bitcoin di Indodax.com. dalam Surat Pemberitahuan Tahunan (selanjutnya disebut SPT) yang kemudian dilaporkan ke Direktorat Jenderal Pajak.

\section{B. RUMUSAN MASALAH}

1. Pemungutan pajak pertambahan nilai terhadap bitcoin sebagai obyek jual beli di indodax.com.

2. Cara menghitung pajak pertambahan nilai yang terutang bitcoin sebagai obyek jual beli di indodax.com.

\section{METODE PENELITIAN}

Penelitian ini menggunakan penelitian hukum normatif yang dilakukan untuk mencari pemecahan masalah atas permasalahan hukum yang ada. Pendekatan yang digunakan dalam penelitian ini adalah pendekatan undang-undang (statute approach) dan pendekatan konseptual (conceptual approach).

\section{PEMBAHASAN}

\section{a. Hubungan Hukum Para Pihak Dalam}

Jual Beli Bitcoin di Indodax.com.

Hubungan hukum para pihak dalam jual beli bitcoin di indodax.com. adalah hubungan antara penjual (buyer) dengan pembeli (seller) melakukan jual beli bitcoin

5 ibid. hal. 126 di indodax.com. Baik penjual maupun pembeli bitcoin sama-sama sebagai member indodax.com. Jika penjual atau pembeli bukan sebagai member indodax.com. maka tidak dapat melakukan jual beli bitcoin di indodax.com. karena bitcoin sebagai obyek jual beli berbentuk aset digital yang diperdagangkan atau diperjualbelikan bagi para member indodax.com. Intinya, bitcoin dijadikan sebagai komoditas perdagangan bagi para member indodax.com. Menurut Pasal 1 angka 2 Undang-Undang Nomor 10 tahun 2011 tentang Perubahan Atas UndangUndang Nomor 32 tahun 1997 tentang Perdagangan Berjangka Komoditi menjelaskan bahwa :

"Komoditi adalah semua barang, jasa, hak dan kepentingan lainnya, dan setiap derivatif dari komoditi, yang dapat diperdagangkan dan menjadi subjek Kontrak Berjangka, Kontrak Derivatif Syariah dan/atau Kontrak Derivatif lainnya."

Di dalam Pasal 1 angka 2 Undang-Undang Nomor 7 Tahun 2014 tentang Perdagangan menjelaskan definisi perdagangan:

"Perdagangan adalah tatanan kegiatan yang terkait dengan transaksi Barang dan/atau Jasa di dalam negeri dan melampaui batas wilayah negara dengan tujuan pengalihan hak atas Barang dan/atau Jasa untuk memperoleh imbalan atau kompensasi."

Berdasarkan Pasal 1 angka 5 Undang-Undang Nomor 7 Tahun 2014 tentang Perdagangan menjelaskan definisi barang:

"Barang adalah setiap benda, baik berwujud maupun tidak berwujud, baik bergerak maupun tidak bergerak, baik dapat dihabiskan maupun tidak dapat dihabiskan, dan dapat diperdagangkan, dipakai, digunakan, atau dimanfaatkan oleh konsumen atau pelaku usaha."

Berdasarkan aturan-aturan hukum tersebut dapat disimpulkan bahwa produk aset digital atau digital asset seperti bitcoin sebagai komoditas barang tidak berwujud yang dapat diperdagangkan telah memiliki landasan Undang-Undang sebagai payung hukum untuk diperdagangkan melalui sistem elektronik. Indodax.com ialah sebuah pasar online atau website tempat jual beli aset digital seperti bitcoin yang dikelola oleh PT. Indodax Nasional Indonesia menggunakan mata uang Rupiah. Menurut CEO Bitcoin Indonesia, Oscar Darmawan menyatakan bahwa Bitcoin hanya merupakan aset digital, bukan alat tukar atau alat pembayaran yang sah. Bitcoin adalah sebuah aset digital yang dikembangkan pada tahun 2009 oleh seseorang dengan nama samaran Satoshi Nakamoto. Bitcoin adalah salah satu bentuk aset digital, komoditas digital maupun bentuk teknologi yang menggunakan konsep desentralisasi dan enkripsi yang dapat diperdagangkan sesama pengguna. Teknologi Bitcoin sendiri tidak berhubungan secara langsung dengan PT. Indodax Nasional Indonesia. Transaksi Bitcoin dapat berjalan tanpa membutuhkan kartu kredit ataupun bank sentral karena Bitcoin diciptakan atau diterbitkan dengan proses yang disebut "Mining" dan menggunakan prinsip teknologi desentralisasi berbasiskan jaringan peer-to-peer (antar muka) atau disebut dengan jaringan blockchain yang diperdagangkan 
di dalam website serta didesain sedemikian rupa untuk memudahkan penggunanya dalam melakukan transaksi perdagangan secara lebih cepat, simple dan efisien menggunakan jaringan internet yang ada. Harga jual beli bitcoin tergantung pada market jual dan market beli serta harga jual beli bitcoin ditentukan oleh para member atau para pengguna bitcoin atau para pemilik akun di indodax.com. Di indodax.com, tidak dapat membeli bitcoin dengan mata uang selain rupiah dan tidak dapat menjual bitcoin ke mata uang selain rupiah karena di Indodax.com. hanya dapat membeli bitcoin dengan mata uang rupiah dan menjual bitcoin ke mata uang rupiah serta dapat menukarkan bitcoin ke aset digital lainnya seperti Litecoin, Dogecoin, Ripple dan Stellar secara gratis. Order Book adalah daftar harga jual dan harga beli yang tersedia di pasar saat ini. Member indodax.com. dapat membeli atau menjual bitcoin menggunakan harga yang tertera di Order Book. Untuk memudahkan member, maka indodax.com. membagi Order Book menjadi dua bagian yaitu :

a. Market Beli adalah daftar permintaan pembelian bitcoin lengkap dengan jumlah harga yang ditawarkan.

b. Market Jual adalah daftar bitcoin yang dijual lengkap dengan jumlah bitcoin dan harga yang diminta.

\section{b. Transaksi Jual Beli Bitcoin di Indodax. com.}

1). Cara Mendaftar Akun di Indodax.com. Sebelum dapat melakukan jual beli bitcoin di Indodax.com, maka langkah pertama adalah mendaftar akun di Indodax.com. Cara mendaftar akun yaitu masukkan nama, e-mail, username, password, dan nomor bandphone. Kemudian verifikasi akun.

\section{2). Cara Verifikasi Akun di Indodax.com.}

Setelah mendaftar akun, lalu verifikasi akun dengan cara masukkan nama lengkap, nomor kartu identitas (KTP/SIM/Passport), alamat lengkap, tempat dan tanggal lahir, scan KTP dan foto diri.

\section{3). Cara Mengaktifkan Google}

\section{Authenticator.}

Google Authenticator adalah sebuah aplikasi yang berguna untuk memperkuat keamanan akun member indodax.com. dari serangan pencuri atau hacker. Aplikasi ini akan menghasilkan PIN yang selalu berubah dari waktu ke waktu. Setelah mengaktifkan Google Authenticator, member indodax.com. diminta memasukkan PIN yang berbeda setiap kali melakukan login akun dan penarikan dana. Fungsi Google Authenticator adalah untuk melindungi akun dari hacker. Hacker adalah orang yang mengakses jaringan komputer secara tidak sah dengan suatu alat dan program tertentu yang bertujuan untuk merusak data dengan mengubah atau mengurangi. Cara mengaktifkan Google Authenticator untuk menjaga keamanan akun yaitu setelah verifikasi akun, klik menu
Google Authenticator di menu indodax.com. Kemudian ada perintah untuk instal Google Authenticator. Agar dapat menginstal Google Authenticator di Android, buka Google Play Store. Cari aplikasi bernama Google Authenticator. Lalu download dan instal aplikasi Google Authenticator. Buka aplikasi Google Authenticator. Pilih Begin setup. Lalu pilih Scan a barcode. Arahkan kamera smartphone pada QRCode di sebelah kanan halaman scan a barcode. Lalu kembali ke halaman utama Google Authenticator, temukan PIN akun. Masukkan PIN tersebut di bawah QRCode. Klik save atau simpan.

\section{4). Cara Melakukan Deposit Rupiah.}

Langkah pertama adalah login akun di indodax.com. Setelah Login Akun, masukkan PIN Google Authenticator. Setelah masukkan PIN Google Authenticator, klik menu Saldo Aset lalu pilih Rupiah. Setelah pilih Rupiah, masukkan jumlah nominal uang Rp.100.000,. Setelah masukkan nominal uang, lalu pilih Metode Bank dan Cara Transfer (ATM, Mobile atau internet banking). Kemudian masukkan Nomor Rekening Bank member indodax.com dan klik lanjutkan. Pilih Metode Pembayaran sesuai keinginan member indodax.com. dan klik tombol pilih di sebelah kanan untuk melihat intruksi lebih lanjut. Setelah mengirimkan uang, mengisi Form Konfirmasi Transfer sesuai data yang diminta. Tunggu tim keuangan Indodax.com. untuk Validasi Deposit. Saldo akan masuk ke dalam Saldo Aset dalam waktu 1-3 jam pada jam kerja.

5). Cara Membeli Bitcoin di Indodax.com.

Langkah pertama adalah login akun di Indodax. com. Setelah login Akun, Masukkan PIN Google Authenticator. Kemudian klik menu Saldo Aset. Lalu klik Deposit/Withdraw pada nama aset Rupiah. Setelah klik Deposit/Withdraw, pilih Transfer Bank. Masukkan Jumlah Saldo Rupiah yang diinginkan untuk membeli Bitcoin dan pilih sumber dana serta metode pembayaran. Tunggu tim keuangan indodax.com untuk Validasi Deposit. Saldo akan masuk dalam 15-60 menit pada jam kerja. Setelah saldo masuk, klik menu Beli/Jual Bitcoin Instan. Kemudian klik Beli Bitcoin. Untuk melakukan pembelian bitcoin secara instan menggunakan harga terbaik di Market Beli pada Order Book dan dikenakan fee sebesar 0,3\% dari jumlah transaksi. Apabila order telah selesai maka saldo bitcoin akan muncul di saldo akun pembeli.

\section{6). Cara Menjual Bitcoin ke Rupiah di Indodax.com.}

Langkah pertama adalah login akun member Indodax.com. Setelah Login Akun, masukkan PIN Google Authenticator. Setelah masukkan PIN Google Authenticator, klik menu Deposit/Withdraw Bitcoin. Kemudian, temukan Alamat Bitcoin Penjual. Setelah ditemukan Alamat Bitcoin tersebut, kirim Bitcoin yang ingin dijual. Tunggu 10-20 menit hingga bitcoin muncul di dalam saldo penjual di Indodax.com. lalu, klik menu Menu Beli/Jual Bitcoin Instan. Kemudian klik menu Jual Bitcoin. Untuk melakukan penjualan bitcoin secara instan menggunakan harga terbaik di Market Jual pada Order Book dan dikenakan fee sebesar 0,3\% dari jumlah transaksi. Apabila order telah selesai maka saldo rupiah 
akan muncul di saldo akun penjual.

\section{c. Pemungutan Pajak Pertambahan Nilai Terhadap Bitcoin Sebagai Obyek Jual Beli di Indodax.com.}

Berdasarkan Pasal 4 ayat (1) Undang-Undang Nomor 42 Tahun 2009 tentang Perubahan Ketiga Atas Undang-Undang Nomor 8 Tahun 1983 tentang Pajak Pertambahan Nilai Barang dan Jasa dan Pajak Penjualan atas Barang Mewah (selanjutnya disebut UU Pajak Pertambahan Nilai Barang dan Jasa dan Pajak Penjualan atas Barang Mewah) adalah pajak yang dikenakan atas :6

a. Penyerahan Barang Kena Pajak di dalam Daerah Pabean yang dilakukan oleh pengusaha;

b. Impor Barang Kena Pajak;

c. Penyerahan Jasa Kena Pajak Tidak Berwujud dari luar Daerah Pabean yang dilakukan oleh pengusaha;

d. Pemanfaatan Barang Kena Pajak Tidak Berwujud dari luar Daerah Pabean di dalam Daerah Pabean;

e. Pemanfaatan Jasa Kena Pajak dari luar Daerah Pabean di dalam Daerah Pabean;

f. Ekspor Barang Kena Pajak Berwujud oleh Pengusaha Kena Pajak;

g. Ekspor Barang Kena Pajak Tidak Berwujud oleh Pengusaha Kena Pajak; dan

h. Ekspor Jasa Kena Pajak.

Subyek Pajak Pertambahan Nilai dikelompokkan menjadi 3 jenis yaitu: ${ }^{7}$

1. Pengusaha Kena Pajak adalah pengusaha yang melakukan penyerahan Barang Kena Pajak dan/atau penyerahan Jasa Kena Pajak yang dikenai pajak berdasarkan Undang-Undang PPN (menurut Pasal 1 angka 15 UndangUndang Pajak Pertambahan Nilai dan Jasa dan Pajak Penjualan atas Barang Mewah) yang wajib melaporkan usahanya untuk dikukuhkan sebagai Pengusaha Kena Pajak, tidak termasuk Pengusaha Kecil, yang batasannya ditetapkan dengan Keputusan Menteri Keuangan, kecuali Pengusaha Kecil yang memilih dikukuhkan sebagai Pengusaha Kena Pajak.

2. Pengusaha kecil dibebaskan dari kewajiban mengenakan atau memungut pajak pertambahan nilai atas penyerahan Barang Kena Pajak dan atau Jasa Kena Pajak, kecuali apabila Pengusaha Kecil memilih untuk dikukuhkan sebagai Pengusaha Kena Pajak menurut Pasal 3 huruf A ayat (2) Undang-Undang Pajak Pertambahan Nilai dan Jasa dan Pajak

6 J. Eko Laksmana, Undang-Undang Pajak Lengkap Tahun 2017 Disertai Undang-Undang Pengampunan Pajak (Tax Amnesty), Mitra Wacana Media, Jakarta, 2017, hal. 261.

7 Deddy Sutrisno dan Indrawati, Op.Cit, hal. 128-129.
Penjualan atas Barang Mewah, Maka UndangUndang Pajak Pertambahan Nilai dan Jasa dan Pajak Penjualan atas Barang Mewah berlaku sepenuhnya bagi Pengusaha Kecil tersebut.

3. Pengusaha Kecil adalah pengusaha yang selama satu tahun buku melakukan penyerahan Barang Kena Pajak dan/atau Jasa Kena Pajak dengan jumlah peredaran bruto tidak lebih dari Rp. 600 juta.

Obyek Pajak Pertambahan Nilai (PPN) ada 2 macam yaitu: ${ }^{8}$

1. Barang Kena Pajak (BKP);

2. Jasa Kena Pajak (JKP).

\section{Barang Kena Pajak (BKP).}

Barang adalah barang berwujud, yang menurut sifat atau hukumnya dapat berupa barang bergerak atau barang tidak bergerak, dan barang tidak berwujud. Barang Kena Pajak adalah barang yang dikenai pajak berdasarkan Undang-Undang Pajak Pertambahan Nilai (selanjutnya disebut UU PPN).

Berdasarkan pasal 4 huruf A ayat (2) UU Pajak Pertambahan Nilai Barang dan Jasa dan Pajak Penjualan atas Barang Mewah, Jenis barang yang tidak dikenai Pajak Pertambahan Nilai adalah barang tertentu dalam kelompok barang sebagai berikut :?

a. Barang hasil pertambangan atau hasil pengeboran yang diambil langsung dari sumbernya;

b. Barang kebutuhan pokok yang sangat dibutuhkan oleh rakyat banyak;

c. Makanan dan minuman yang disajikan di hotel, restoran, rumah makan, warung, dan sejenisnya, meliputi makanan dan minuman baik yang dikonsumsi di tempat maupun tidak, termasuk makanan dan minuman yang diserahkan oleh usaha jasa boga atau katering; dan

d. Uang, emas batangan, dan surat berharga.

Yang termasuk dalam pengertian penyerahan Barang Kena Pajak berdasarkan Pasal 1 huruf A ayat (1) UU Pajak Pertambahan Nilai Barang dan Jasa dan Pajak Penjualan atas Barang Mewah adalah: ${ }^{10}$

a. Penyerahan hak atas Barang Kena Pajak karena suatu perjanjian;

b. Pengalihan Barang Kena Pajak oleh karena suatu perjanjian sewa beli dan/atau perjanjian sewa guna usaha (leasing);

c. Penyerahan Barang Kena Pajak kepada pedagang perantara atau melalui juru lelang;

8 ibid. hal.129.

9 J. Eko Laksmana, Op.Cit., hal. 261.

$10 \mathrm{ibid}$. hal. 259. 
d. Pemakaian sendiri dan/atau pemberian cumacuma atas Barang Kena Pajak;

e. Barang Kena Pajak berupa persediaan dan/atau aktiva yang menurut tujuan semula tidak untuk diperjualbelikan, yang masih tersisa pada saat pembubaran perusahaan;

f. Penyerahan Barang Kena Pajak dari pusat ke cabang atau sebaliknya dan/atau penyerahan Barang Kena Pajak antar cabang;

g. Penyerahan Barang Kena Pajak secara konsinyasi; dan

h. Penyerahan Barang Kena Pajak oleh Pengusaha Kena Pajak dalam rangka perjanjian pembiayaan yang dilakukan berdasarkan prinsip syariah, yang penyerahannya dianggap langsung dari Pengusaha Kena Pajak kepada pihak yang membutuhkan Barang Kena Pajak.

Yang tidak termasuk dalam pengertian penyerahan Barang Kena Pajak menurut Pasal 1 huruf A ayat (2) UU Pajak Pertambahan Nilai Barang dan Jasa dan Pajak Penjualan atas Barang Mewah adalah: ${ }^{11}$

a. Penyerahan Barang Kena Pajak kepada makelar sebagaimana dimaksud dalam Kitab Undangundang Hukum Dagang;

b. Penyerahan Barang Kena Pajak untuk jaminan utang-piutang;

c. Penyerahan Barang Kena Pajak sebagaimana dimaksud dalam ayat (1) huruf $\mathrm{f}$ dalam hal Pengusaha Kena Pajak melakukan pemusatan tempat pajak terutang;

d. Pengalihan Barang Kena Pajak dalam rangka penggabungan, peleburan, pemekaran, pemecahan, dan pengambilalihan usaha dengan syarat pihak yang melakukan pengalihan dan yang menerima pengalihan adalah Pengusaha Kena Pajak; dan

e. Barang Kena Pajak berupa aktiva yang menurut tujuan semula tidak untuk diperjualbelikan, yang masih tersisa pada saat pembubaran perusahaan, dan yang Pajak Masukan atas perolehannya tidak dapat dikreditkan.

\section{Jasa Kena Pajak (JKP) ${ }^{12}$}

Jasa adalah setiap kegiatan pelayanan yang berdasarkan suatu perikatan atau perbuatan hukum yang menyebabkan suatu barang, fasilitas, kemudahan, atau hak tersedia untuk dipakai termasuk jasa yang dilakukan untuk menghasilkan barang karena pesanan atau permintaan dengan bahan dan atas petunjuk dari pemesanan.

Jasa Kena Pajak adalah jasa yang dikenai pajak

11 ibid. hal. 259-260.

12 Deddy Sutrisno dan Indrawati, Op.Cit., hal.131. berdasarkan Undang-Undang PPN.

Jenis jasa yang tidak dikenai Pajak Pertambahan Nilai adalah jasa tertentu dalam kelompok jasa berdasarkan Pasal 4 huruf A ayat (3) UU Pajak Pertambahan Nilai Barang dan Jasa dan Pajak Penjualan atas Barang Mewah adalah sebagai berikut: ${ }^{13}$

a. Jasa pelayanan kesehatan medis;

b. Jasa pelayanan sosial;

c. Jasa pengiriman surat dengan perangko;

d. Jasa keuangan;

e. Jasa asuransi;

f. Jasa keagamaan;

g. Jasa pendidikan;

h. Jasa kesenian dan hiburan;

i. Jasa penyiaran yang tidak bersifat iklan;

j. Jasa angkutan umum di darat dan di air sertajasa angkutan udara dalam negeri yang menjadi bagian yang tidak terpisahkan dari jasa angkutan udara luar negeri;

k. Jasa tenaga kerja;

1. Jasa perhotelan;

m. Jasa yang disediakan oleh pemerintah dalam rangka menjalankan pemerintahan secara umum;

n. Jasa penyediaan tempat parkir;

o. Jasa telepon umum dengan menggunakan uang logam;

p. Jasa pengiriman uang dengan wesel pos.

Pemungut Pajak Pertambahan Nilai adalah bendahara pemerintah, badan, atau instansi pemerintah yang ditunjuk oleh Menteri Keuangan untuk memungut, menyetor, dan melaporkan pajak yang terutang oleh Pengusaha Kena Pajak atas penyerahan Barang Kena Pajak dan/atau penyerahan Jasa Kena Pajak kepada bendahara pemerintah, badan, atau instansi pemerintahan tersebut. ${ }^{14}$ Sistem Pajak Pertambahan Nilai (selanjutnya disebut PPN) menganut tarif tunggal yaitu sebesar 10\% (sepuluh persen) untuk impor Barang Kena Pajak, Penyerahan Barang Kena Pajak dan/atau Jasa Kena Pajak, pemanfaatan Barang Kena Pajak tidak berwujud dan atau Jasa Kena Pajak dari Luar Daerah Pabean. Namun demikian tarif tersebut dapat diubah menjadi paling rendah 5\% (lima persen) dan paling tinggi 15\% (lima belas persen) yang perubahan tarifnya diatur oleh Peraturan Pemerintah. ${ }^{15}$

13 J. Eko Laksmana, Op.Cit., hal. 261.

14 Deddy Sutrisno dan Indrawati, Op.Cit., hal.132.

15 ibid. hal.136. 
Berdasarkan aturan-aturan hukum diatas dapat diketahui bahwa bitcoin termasuk Barang Kena Pajak yang tidak berwujud yang diperjualbelikan atau diperdagangkan bagi para member di indodax.com. karena mulai Tanggal 9 November 2016, semua biaya untuk jual beli bitcoin yang terjadi di indodax.com. sudah termasuk Pajak Pertambahan Nilai (PPN) sebesar $10 \%$. Para member selaku para pelaku perdagangan (traders) yang melakukan jual beli bitcoin di Indodax. com. seharusnya menyertakan pendapatannya dari perdagangan bitcoin di indodax.com. atau memasukkan setiap keuntungan yang diperoleh dari kegiatan trading bitcoin di Indodax.com. dalam Surat Pemberitahuan Tahunan (selanjutnya disebut SPT) kemudian dilaporkan ke Direktorat Jenderal Pajak.

Pemungutan PPN dilaksanakan berdasarkan sistem faktur pajak. Setiap terjadinya penyerahan barang kena pajak atau jasa kena pajak wajib dibuatkan faktur pajak berdasarkan Pasal 13 ayat (1) dan ayat (1) huruf a Undang-Undang Pajak Pertambahan Nilai Barang dan Jasa dan Pajak Penjualan atas Barang Mewah. Menurut pasal 1 angka 23 Undang-Undang Pajak Pertambahan Nilai Barang dan Jasa dan Pajak Penjualan atas Barang Mewah menyatakan bahwa faktur pajak merupakan bukti pungutan PPN. Faktur pajak bagi penjual merupakan bukti pajak keluaran. Bagi penjual atau Pengusaha Kena Pajak, pajak yang dipungut dari pembeli termasuk pajak keluaran menurut Pasal 1 angka 25 Undang-Undang Pajak Pertambahan Nilai Barang dan Jasa dan Pajak Penjualan atas Barang Mewah. Sedangkan faktur pajak bagi pembeli merupakan bukti pajak masukan. Bagi pembeli yang dibebani membayar PPN oleh Penjual termasuk pajak masukan menurut Pasal 1 angka 24 Undang-Undang Pajak Pertambahan Nilai Barang dan Jasa dan Pajak Penjualan atas Barang Mewah.

Sebelum Bitcoin sebagai Barang Kena Pajak diserahkan oleh member indodax.com (selaku penjual bitcoin) ke member indodax.com yang lain (selaku pembeli bitcoin) melalui indodax.com maka penjual bitcoin selaku Pengusaha Kena Pajak wajib memungut PPN yang terutang kepada Pembeli Bitcoin tersebut. Sebelum Bitcoin sebagai Barang Kena Pajak dijual oleh member indodax.com (selaku penjual bitcoin) ke member indodax.com yang lain (selaku pembeli bitcoin), utang PPN dibebankan ke Pembeli bitcoin dan utang PPN tersebut dimasukkan ke harga jual bitcoin. Utang PPN yang dibebankan kepada pembeli bitcoin oleh penjual bitcoin yang selaku Pengusaha Kena Pajak tersebut termasuk pajak masukan. Sedangkan Penjual bitcoin yang memungut PPN terutang ke Pembeli tersebut termasuk pajak keluaran.

\section{d. Cara Menghitung Pajak Pertambahan Nilai yang Terutang Terhadap Bitcoin sebagai Obyek Jual Beli di Indodax. com.}

Dalam menghitung Pajak Pertambahan Nilai (PPN), maka yang harus diperhatikan adalah tarif Pajak, Dasar Pengenaan Pajak dan Sistem Pengenaan Pajak menggunakan Sistem Faktur. Tarif PPN yang terutang menurut Pasal 7 ayat (1) UU Pajak Pertambahan Nilai
Barang dan Jasa dan Pajak Penjualan atas Barang Mewah sebesar 10\% 9sepuluh persen). Dasar pengenaan Pajak adalah harga jual, penggantian, nilai impor, nilai ekspor, atau nilai lain yang dipakai sebagai dasar untuk menghitung pajak yang terutang ditetapkan oleh Keputusan Menteri Keuangan Nomor 267 Tahun 2000 tentang Nilai Lain sebagai Dasar Pengenaan Pajak. Rumus menghitung PPN adalah PPN Terutang $=$ Tarif Pajak x Dasar Pengenaan Pajak. ${ }^{16}$

Misalnya harga jual bitcoin di indodax.com. sebesar Rp. 50.000,- (lima puluh ribu rupiah). Berapa PPN yang terutang yang harus dibayar oleh member indodax.com. sebagai pembeli bitcoin di indodax.com?

Jawab: cara menghitung PPN-nya :

PPN Terutang $=$ Tarif Pajak $x$ Dasar Pengenaan Pajak. $=10 \% \times$ Rp. $50.000,-=$ Rp. 5.000,

Jadi PPN yang harus dibayar oleh member indodax. com. sebagai pembeli bitcoin di indodax.com sebesar Rp. 5.000,- (lima ribu rupiah).

\section{E. SIMPULAN}

Sebelum Bitcoin sebagai Barang Kena Pajak diserahkan oleh member indodax.com (selaku penjual bitcoin) ke member indodax.com yang lain (selaku pembeli bitcoin) melalui indodax.com maka penjual bitcoin selaku Pengusaha Kena Pajak wajib memungut PPN yang terutang kepada Pembeli Bitcoin tersebut. Sebelum Bitcoin sebagai Barang Kena Pajak dijual oleh member indodax.com (selaku penjual bitcoin) ke member indodax.com yang lain (selaku pembeli bitcoin), utang PPN dibebankan ke Pembeli bitcoin dan utang PPN tersebut dimasukkan ke harga jual bitcoin. Utang PPN yang dibebankan kepada pembeli bitcoin oleh penjual bitcoin yang selaku Pengusaha Kena Pajak tersebut termasuk pajak masukan. Sedangkan Penjual bitcoin yang memungut PPN terutang ke Pembeli tersebut termasuk pajak keluaran.

Para member indodax.com. selaku para pelaku perdagangan (traders) yang melakukan jual beli bitcoin di Indodax.com. masih ada yang belum menyertakan pendapatannya dari perdagangan bitcoin di indodax. com. atau belum memasukkan setiap keuntungan yang diperoleh dari kegiatan trading bitcoin di Indodax.com. dalam Surat Pemberitahuan Tahunan (selanjutnya disebut SPT) yang kemudian dilaporkan ke Direktorat Jenderal Pajak. Berdasarkan Undang-Undang Nomor 42 Tahun 2009 tentang Perubahan Ketiga Atas Undang-Undang Nomor 8 Tahun 1983 tentang Pajak Pertambahan Nilai Barang dan Jasa dan Pajak Penjualan atas Barang Mewah dapat disimpulkan bahwa bitcoin termasuk Barang Kena Pajak yang tidak berwujud yang diperjualbelikan atau diperdagangkan bagi para member di indodax.com. karena mulai tanggal 9 November 2016, semua biaya untuk jual-beli bitcoin yang terjadi di indodax.com. sudah termasuk Pajak Pertambahan Nilai (PPN) sebesar $10 \%$.

16 ibid. hal 134 


\section{F. DAFTAR PUSTAKA}

1. Deddy Sutrisno dan Indrawati, Bahan Ajar Mata Kuliah Hukum Pajak, Fakultas Hukum Universitas Airlangga, Surabaya, 2009.

2. J. Eko Laksmana, Undang-Undang Pajak Lengkap Tahun 2017 Disertai Undang-Undang Pengampunan Pajak (Tax Amnesty), Mitra Wacana Media, Jakarta, 2017.

3. R. Santoso Brotodiharjo, Pengantar Ilmu Hukum Pajak, Refika Aditama, Bandung, 2005.

4. Rochmat Soemitro, Asas dan Dasar Perpajakan, Refika Aditama, Bandung, 2005.

5. Undang - Undang Nomor 7 Tahun 2014 tentang Perdagangan.

6. Undang - Undang Nomor Tahun 2011 tentang Perubahan Atas Undang-Undang Nomor 32 Tahun 1997 tentang Perdagangan Berjangka Komoditi.

7. Undang-Undang Nomor 42 Tahun 2009 tentang Perubahan Ketiga Atas Undang-Undang Nomor 8 Tahun 1983 tentang Pajak Pertambahan Nilai Barang dan Jasa dan Pajak Penjualan atas Barang Mewah. 
